6. FERREE, C. E., RAND, G., and Lewis, E. F.-Age as an important factor in the amount of light needed by the eye. Arch. of Ophthal., Vol. XIII, pp. 212-226, 1935.

7. Ferree, C. E., and Rand, G.-Light Sense and Adaptation. Tabulae Biologicae, Holland. In Press.

8. - A new type of instrument for testing the light and color sense. Amer. Jl. of Ophthal., Vol. XIV, pp. 325-333, 1931. The testing of fitness for night flying: the light sense. Ibid., Vol. XX, pp. 797-808, 1937.

9. A convenient device for using artificial pupils of different sizes. Ibid., pp. 632-634, 1932.

10. Some experiments on the eye with different illuminants. Part I. Trans. Ill. Eng. Soc., Vol. XIII, pp. 50-60, 1918.

11. - Intensity of light in relation to the examination of the eye. Brit. Jl. of Ophthal., Vol. XX, pp. 331-346, 1936.

\title{
APLASIA OF THE OPTIC NERVES
}

BY

\section{HAROLD RIDLEY}

LONDON

THE following is an account of a rare condition seen in $\mathrm{Mr}$. Rupert Scott's clinic at the Royal London Ophthalmic Hospital.

T.V., aged one year, an only child, was brought by his mother, who suspected blindness. There was no history of any ocular defect in either the paternal or maternal families. The mother stated that the child did not appear to follow light, but that she thought it possible that he was conscious of bright sunlight.

On examination, the child did not follow light at all. The anterior portions of the eyes were quite normal. There was no nystagmus. The pupils were inactive to light but varied in size from time to time, apparently irrespective of stimulus. The media were clear. The fundi presented the peculiar appearance shown in the drawing. The red reflex was pale, especially at the periphery, and the choroidal pattern very well marked. In place of a normal optic disc was a deep excavation, the base of which appeared to focus about 5 dioptres beyond the general retinal level. The colour was grey. From the base of the pit emerged only minute threads representing retinal vessels, the lower branch in the right eye being the only one which contained more than a trace of blood, and even this appeared to fade out soon after leaving the edge of the excavation.

Cases of complete or even partial aplasia of the optic nerve are very rare, and very few are on record. They are nearly always accompanied by severe deformity, such as anencephaly, hydrocephalus (Rosenbaum), or at least mental defect (Zeeman and Tumbelaka). The majority of cases in the literature are those with approximately normal retinal vessels, but with the optic disc either very small (Velhagen), or even absent (Briere, Hawley, Schwarz). 


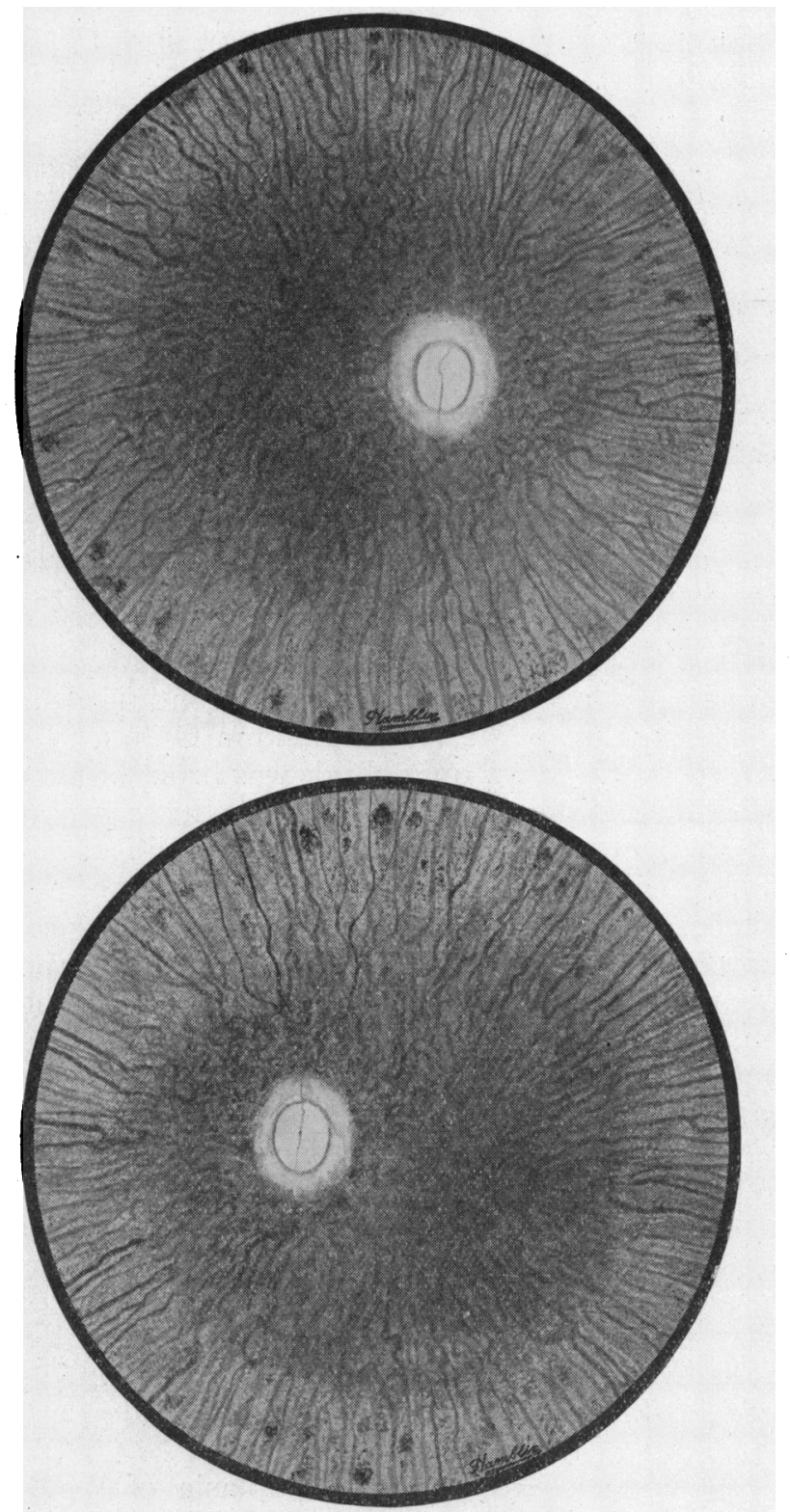

A fundus drawing of the case described.

The only case discovered resembling the one described is that of Szymanski, which occurred in a cat. The case was discovered quite accidentally and one eye only was abnormal. The optic disc was represented by a cavity from which emerged only strandlike vessels containing very little blood. It was fortunate that the 


\section{Aplasia of The Optic Nerves}

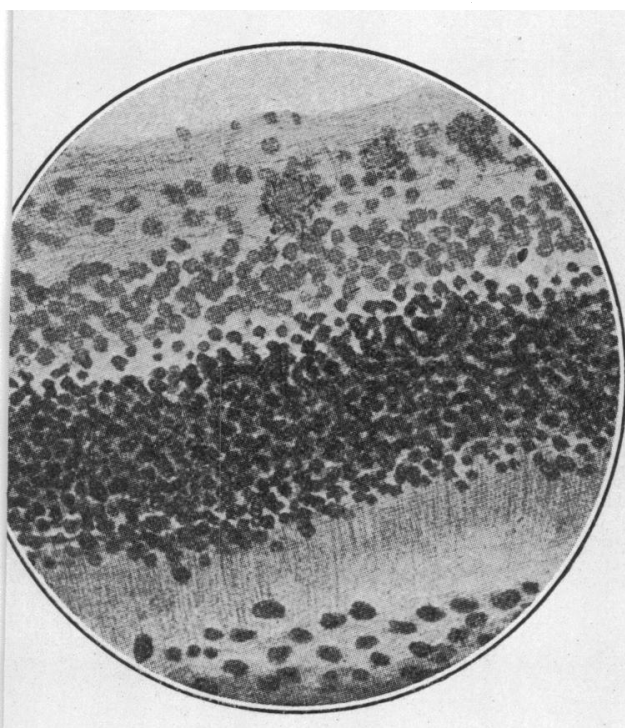

Normal cat's retina.

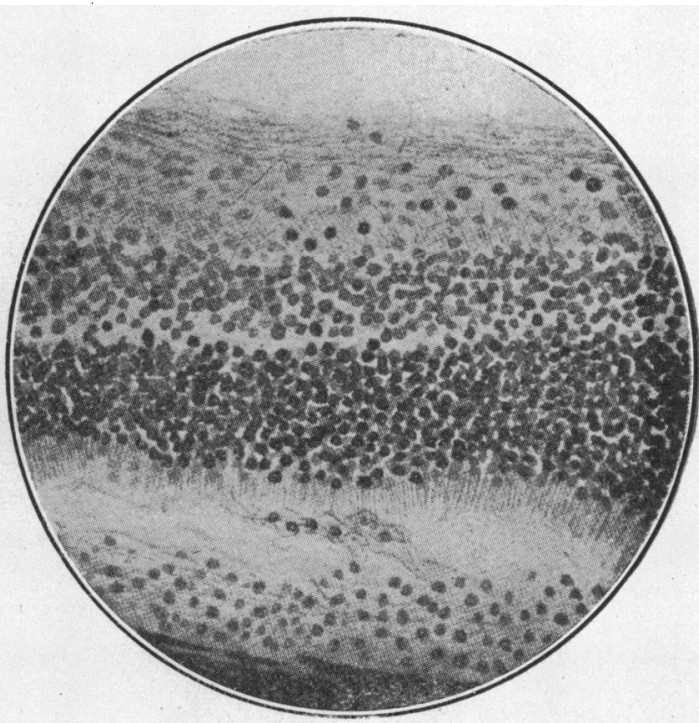

Abnormal retina showing absence of ganglion cells.

Microscopical sections of retina of Szymanski's cat.

abnormality occurred in a lower animal, as it permitted excision of the eye and microscopical examination. This showed complete absence of the ganglion cell and nerve fibre layers of the retina, though the external layers were present. It seems highly probable that a similar condition would be discovered if section of these human eyes were possible.

My thanks are due to the Staff at Moorfields, and in particular to Mr. Rupert Scott and Miss Ida Mann for their help and their permission to publish this case.

\section{REFERENCES}

Brière.-Absence des papilles; cecité absolue. Ann. d'Ocul., Vol. LXXVIII, p. $41,1877$.

Rosenbaum, S.-Beiträge zur Aplasie des Nervus opticus. Diss., Marburg, 1902. Hlso in Zeitschr. f. Augenheilk., Vol. VII, pp. 200-213, 1902.

Hawley, C. W.-Congenital absence of optic disc. Ophthal. Record, Vol. XX, pp. 27-28, 1911.

KraUss.-Demonstration eines sehr seltenen Augenhintergrundbefundes mit Verlagerung der Durchtrittsstelle der Zentralgefässe. Ber. d. Ophthal. Ges. Heidelberg. Vol. XXXIX pp. 380-382, 1913.

SCHWARZ, O.-Ein I-all von mangelhafter Bildung (Hypoplasie) beider Sehnerven. Arch. f. Ophthal., Vol. XC, pp. 326-328, 1915.

ZEeman, W. P. C., and TUMBELAKA, R.-Das zentrale und periphere optische System bei einer kongenital blinden Katze. Arch.f. Ophthal., Vol. XCI, pp. 242-263, 1916.

Cords, R.-Einseitige Kleinheit der Papille. Klin. Monatsbl. f. Augenheilk., Vol. LXXI, pp. 414-418, 1923.

SzYMANSKI.- - Les altérations rétiniennes dans l'oeil d'un chat privé de papille. Bull. Soc. franc d'Ophtal., Vol. XXXIX, pp. 265-272, 1926.

VelHaGEN, C.- - Ein Fall von einseitiger Hypoplasie des Sehnerven in einem sonst normalen Augapfel. Arch.f. Augenheilk., Vol. CII, pp. 382-386, 1930.

DUKE-Elder, Sir W.-Text-book of Ophthalmology. Vol. II, p. 1341, 1938.

MANN, Miss IDA.-Developmental Abnormalities of the Eye. 1937. 